Available online at GSC Online Press Directory

GSC Biological and Pharmaceutical Sciences

e-ISSN: 2581-3250, CODEN (USA): GBPSC2

Journal homepage: https://www.gsconlinepress.com/journals/gscbps

(RESEARCH ARTICLE)

\title{
Phytochemical screening, in vitro antibacterial and partial TLC purification of different solvents extracts of Ocimum basilicum L
}

\author{
Yelwa Abubakar Sani ${ }^{1}$, Ogbiko Cyril 1, ${ }^{*}$, Yakubu Yahaya ${ }^{2}$, Usman Hassan ${ }^{3}$ and Lawal Sherifat Ibrahim ${ }^{3}$ \\ ${ }^{1}$ Department of Pure and Applied Chemistry, Faculty of Science, Usmanu Danfodiyo University Sokoto, Sokoto State, Nigeria. \\ 2 Department of Pure and Applied Chemistry, Kebbi State University of Science and Technology Aliero, Kebbi State Nigeria. \\ ${ }^{3}$ Department of Chemistry, College of Preliminary Studies, Yelwa - Yauri, Kebbi State Nigeria.
}

Publication history: Received on 01 November 2018; revised on 27 November 2018; accepted on 28 November 2018

Article DOI: https://doi.org/10.30574/gscbps.2018.5.2.0127

\begin{abstract}
Ocimum basilicum $L$ is commonly used in Nigeria folk medicine for healing various diseases. In a continuous bid to explore new biocompatible antimicrobial agents with the least associated side effects, different solvents extract of $O$. basilicum were challenged with common pathogenic microorganisms at varying concentrations. The phytochemical screening, antimicrobial activity and the partial TLC purification of the different solvents extract were performed using standard procedures. The phytochemical analysis revealed the presence of various pharmaceutically active secondary metabolites like phenolic, flavonoids, carbohydrates, glycosides, tannins among others. Using the zone of inhibition as inhibitory parameter, the crude aqueous extract exhibited the best antibacterial activity among all the other solvent extracts but was lower than the standard drug ciprofloxacin which exhibited a near $100 \%$ activity for all microorganism screened. In conclusion, the plant leaves possesses various potentially active secondary metabolites which would help in developing pharmaceuticals especially antimicrobial drugs.
\end{abstract}

Keywords: Ocimum basilicum; Phytochemical; Antimicrobial activity; TLC

\section{Introduction}

Since decades, plants and their parts are well known for their bioactive constituents responsible for the therapeutic effects [1-3]. Medicinal plants are useful for healing and as well for curing human diseases because of the presence of phytochemical constituents [4]. They are rich in phytochemicals which offer defense mechanism and protection from various diseases [5]. As a result of the increase in the incidence of side effects and the resistance that pathogenic microorganisms build against several antibiotics, research on medicinal plants has attracted a lot of attentions globally [6-8], hence, the need to screen for potent therapeutic agents from plants origin which are easily accessible, cheaper and have bearable side effects.

Ocimum basilicum L. commonly called "king of herbs" belongs to the family Lamiaceace [9]. It is an annual plant usually producing white-purple flowers [10]. It is a culinary herb consumed in high quantity due to the characteristic flavors it imparts. The plant is found in many parts of the world especially in the tropical regions of Asia, Africa and Central and South America [11-12]. It contains many phytochemical compounds which manifests various health benefits [13]. Though much antibacterial and phytochemical studies has been conducted on Ocimum species, the present work has been designed to challenge different solvents extract of the plant against common pathogens with a view to screening for its antimicrobial activity, validating its traditional use and attempt to partially purify the different solvents extract using TLC.

\footnotetext{
${ }^{*}$ Corresponding author

E-mail address: cyril.ogbiko@udusok.edu.ng
}

Copyright (C) 2018 Author(s) retain the copyright of this article. This article is published under the terms of the Creative Commons Attribution Liscense 4.0. 


\section{Material and methods}

\subsection{Plant materials collection, preparation and identification}

The fresh plant materials of Ocimum basilicum (locally called Doddoya in Hausa) was collected at Baha area of Yauri town, Kebbi State in May, 2016 by hand picking. The leaves were washed under running tap water to remove earthy impurities. They were placed in sterile containers and transported to the Department of Pharmaceutical Microbiology Laboratory, Faculty of Pharmaceutical Sciences, Usmanu Danfodiyo University Sokoto Nigeria for analysis. Botanical identification and authentication of the sample was done by a plant Taxonomist of the Department of Botany, Faculty of Science, Usmanu Danfodiyo University Sokoto Nigeria where a herbarium specimen was deposited and a voucher number issued. They were then dried under shade for three weeks, powdered with the aid of a clean mechanical grinder and stored in an air tight glass container until use.

\subsection{Chemicals}

Methanol (Merck India), acetone (Merck India), n - hexane (Sigma Aldrich), ethyl acetate (Sigma Aldrich), and other chemicals and reagents used for the research were all of analytical grade.

\subsection{Soxhlet extraction}

The powdered leaves were extracted using a Soxhlet apparatus with analytical grade $\mathrm{n}-$ hexane. The cycles were repeated until complete defatting was obtained. The crude extract was then dried at room temperature to constant weight. This was the crude $\mathrm{n}$ - hexane leaves extract (CNE). The same procedure was repeated separately for three fractions, namely ethyl acetate, methanol and water fractions to obtain the CEE, CME and CAE respectively. All the fractions were stored at $4{ }^{\circ} \mathrm{C}$ till use.

\subsection{Phytochemical analysis}

Simple chemical tests to detect the presence of carbohydrates, proteins and secondary metabolites in the powdered $O$. basilicum leaves were done in accordance with standard methods [14-16].

\subsection{Collection of the microorganisms}

Standard laboratory strains of Staphylococcus aureus, Escherichia coli, Bacillus subtilis and Proteus spp. were obtained from the Department of Pharmaceutical Microbiology, Usmanu Danfodiyo University Teaching Hospital Sokoto, Sokoto State Nigeria.

\subsection{Confirmation of test organisms}

Biochemical analysis methods as described by [17-19] were carried out on each of the test bacteria isolates for confirmation. The Bergey's Manual of Systematic Bacteriology [20] was used for species authentication.

\subsection{Preparation of culture medium}

The preparation of this medium was based on the manufacturer's specification and sterilization was by autoclaving at $121^{\circ} \mathrm{C}$.

\subsection{Preparation of standard bacterial suspensions}

The average number of viable, bacterial organisms per $\mathrm{ml}$ of the stock suspensions was determined by means of the surface viable counting technique [21]. About $10^{8}-10^{9}$ colony forming units per ml were used. Each time, a fresh stock suspension was prepared; the experimental conditions were maintained constant so that suspensions with very close viable counts would be obtained [22].

\subsection{Susceptibility test}

The agar well diffusion method was used with slight modification [23]. The nutrient agar was prepared by dissolving accurately weighed $14 \mathrm{~g}$ of the agar into $500 \mathrm{~cm}^{3}$ of distilled water. The prepared agar was heated over a Bunsen burner to dissolve completely and it was dispensed in $20 \mathrm{~cm}^{3}$ of universal bottles, and then autoclaved at $121^{\circ} \mathrm{C}$ for 20 minutes. It was allowed to cool and then distributed into sterilized Petri dishes (which have been sterilized at $170{ }^{\circ} \mathrm{C}$ for 1 hour) and allowed to set. After setting, the Petri dish was flooded with $1 \mathrm{~cm}^{3}$ of the standardized culture of various dilutions of the test bacteria and the excess was drained using a Pasteur pipette. Wells measuring $6 \mathrm{~mm}$ in diameter were bored 
into the inoculated Petri dishes using a cork borer. The wells were sealed by a drop of melted nutrient agar and were filled with $0.05 \mathrm{~cm}^{3}$ each of $10 \mathrm{mg} / \mathrm{cm}^{3}, 20 \mathrm{mg} / \mathrm{cm}^{3}, 30 \mathrm{mg} / \mathrm{cm}^{3}$ and $40 \mathrm{mg} / \mathrm{cm}^{3}$ of the CNE, CEE, CME and CAE fractions respectively. The plates were allowed to stand for 2 hours for pre-diffusion and then incubated for 24 hours at $37{ }^{\circ} \mathrm{C}$. The zone of inhibition was measured to the nearest millimeters using a metric rule. 10\% Tween-40 (50 $\mu \mathrm{L})$ and Ciprofloxacin $(20 \mu \mathrm{g} / \mathrm{mL})$ was used as the negative and positive control respectively. All readings were performed in triplicate.

\subsection{TLC partial purification of the fractions of $O$. basilicum}

TLC was performed on pre-coated TLC plates with silica gel $\mathrm{F}_{254}$ (layer thickness $0.2 \mathrm{~mm}$, E. Merck, Darmstadt, Germany). $8 \mathrm{~cm}^{3}$ of n-hexane and $2 \mathrm{~cm}^{3}$ of ethyl acetate were used as the solvent system. A line was drawn on the TLC plate to serve as the origin. A capillary tube was used to spot the n-hexane extract on the TLC plates and then placed in the solvent system. The distance travelled by the solvent was measured using a ruler. The same procedure was performed for the ethyl acetate and methanol fractions with ethyl acetate and n-hexane (8:2) and chloroform and methanol (5:1) were used as solvent systems respectively. To ensure accuracy of determination and also for compounds that are colorless, the TLC plate was viewed under ultraviolet (UV) light at $254 \mathrm{~nm}$ as well as inserting the TLC plate in iodine vapors for a few minutes.

\section{Results and discussion}

\subsection{Percentage yield of the crude methanol extract and fractions}

The percentage yield of the n-hexane (CNE), ethyl acetate (CEE), methanol (CME) and the aqueous (CAE) are presented in Table 1.

Table 1 Percentage yield of the different solvents used in extracting the 0 . basilicum

\begin{tabular}{ll}
\hline Fractions & \% Yield \\
\hline CNE & 25.51 \\
CEE & 2.77 \\
CME & 3.76 \\
CAE & 67.68 \\
\hline
\end{tabular}

\subsection{Phytochemical screening}

Table 2 Preliminary phytochemical screening of the leaves of $O$. basilicum

\begin{tabular}{llll}
\hline Phytochemicals & Test & Observation & Inference \\
\hline Saponin & Frothing & Foam was formed & + \\
Flavonoid & Shinoda's & Reddish colour was observed & + \\
& Alkaline reagents & Intense yellow colour was formed & Blue black colour appeared \\
Tannins & Ferric chloride & Coloured precipitate appeared & + \\
& Lead sub acetate & No change was observed & + \\
Anthraquinone & Borntrager's & Bluish black colour appeared & - \\
Phenols & Ferric chloride & No precipitate formed & + \\
Alkaloid & Mayer's & No precipitate formed & - \\
& Wagner's & No precipitate formed & - \\
Carbohydrate & Dragendroff's & Violet ring was formed at the junction & - \\
Polyphenol/triterpenoids & Molich's & Red precipitate was formed & + \\
& Fehling's & Appearance of golden yellow ring at the & + \\
& & interface & + \\
Cardiac glycosides & Libermann Burchard's & Formation of brown ring at the junction & - \\
\hline
\end{tabular}


The result of the phytochemical analysis of the leaves of 0 . basilicum is presented in Table 2 . The results of the phytochemical screening are similar with the results obtained by several researchers [24-26]. The presence of these phytochemicals is responsible for the diverse tradomedical application of the plant.

\subsection{Antimicrobial screening}

The result presented in Figure 1 reveals the in vitro susceptibility of the bacteria isolates to the crude fractions of $O$. basilicum. The results shows the mean \pm standard deviation of the inhibition zone $(\mathrm{mm})$ for triplicate determination in the various agar plates of bacteria exposed to the extract fractions compared to the standard drug ciprofloxacin.

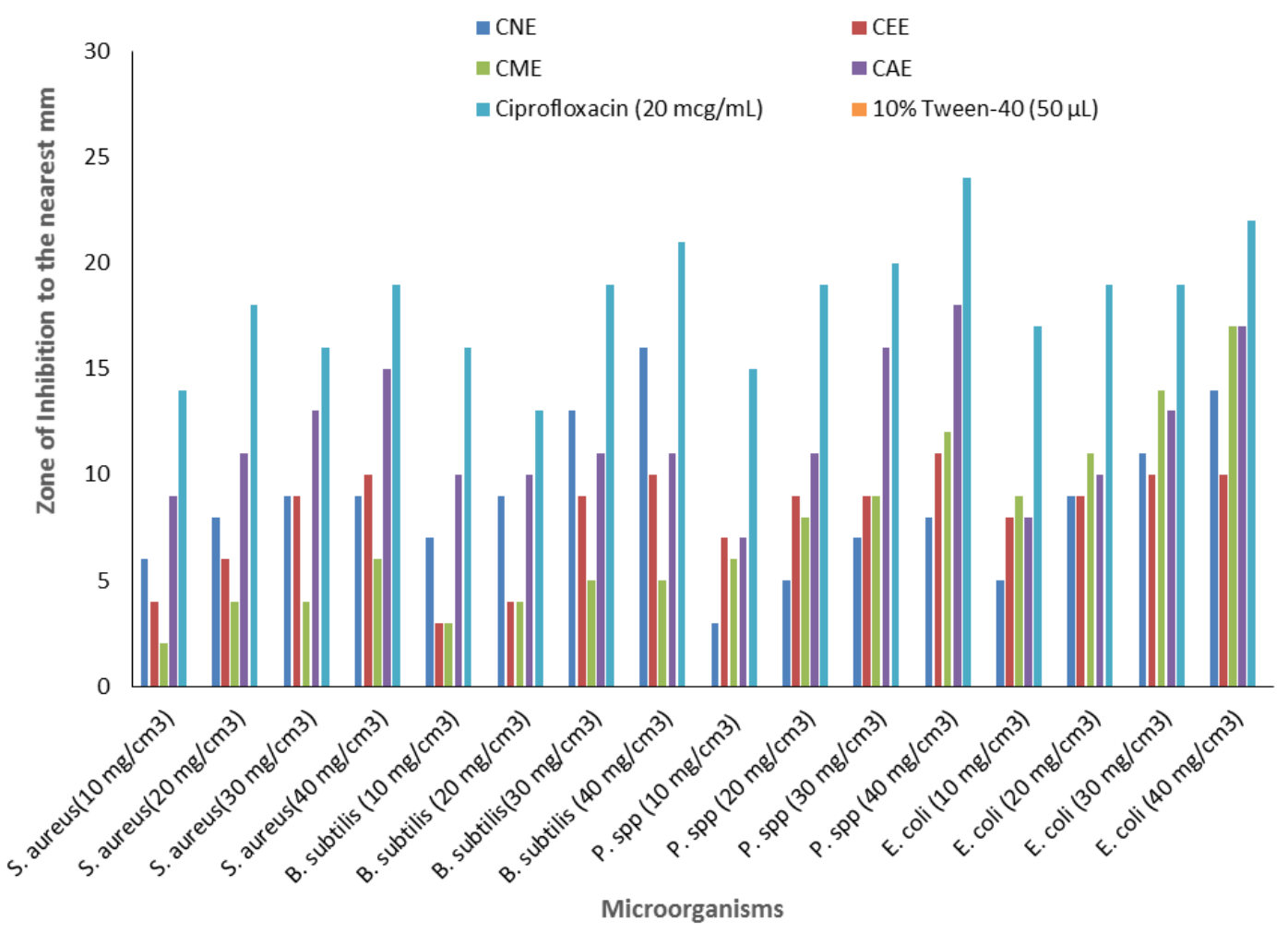

Figure 1 Antimicrobial activity (zone of inhibition) of $O$. basilicum crude extract fractions against various human pathogens $(\mathrm{CNE}=$ Crude $\mathrm{n}$-hexane extract, $\mathrm{CEE}=$ crude ethyl acetate extract, $\mathrm{CME}=$ crude methanol extract, $\mathrm{CAE}=$ crude aqueous extract).

Natural antimicrobial compounds from plants are now been explored since they not only offer therapeutics influence but offer fewer side effects when compared to synthetic antimicrobial agents. The different solvent extract showed varying activity against the bacteria isolates investigated with the CAE showing stronger and broader spectrum of antimicrobial activity compared to other solvent extracts. Highest zone of inhibition of $18 \mathrm{~mm}$ was observed at 40 $\mathrm{mg} / \mathrm{ml}$ concentration of the CAE against $P$. spp while the least activity was exhibited by the CME at $10 \mathrm{mg} / \mathrm{ml}$ with a zone of inhibition of $2 \mathrm{~mm}$ when challenge with S. aureus. While the $10 \%$ Tween - 40 solutions showed no activity, the ciprofloxacin exhibited a $100 \%$ or near $100 \%$. The antimicrobial activity recorded for the different solvents extract are in agreement with the report of Adiguzel et al., [27], Adamu et al., [28], Adam and Omer, [29] who all reported the antibacterial activities of different extracts of 0 . basillicum leaves against several bacterial strains using different methods. The antimicrobial results also agrees with the findings of Cooper et al., [30] who reported that the presence of more group of phytochemical diversity gives synergic effects in many biological applications. The disparity between the activities of the extracts and the standard antimicrobial drugs may be due to the mixtures of bioactive compounds present in the extracts compared to the pure compound contained in the standard antibiotics [31].

\subsection{Partial purification of the fractions of $O$. basilicum using TLC}

The result of the T.L.C partial purification of the CNE, CEE and CME fractions 0 . basilicum are presented tables $3-5$ 
Table 3 TLC purification of the CNE extract

\begin{tabular}{ll}
\hline Spot & Rf value \\
\hline A & 0.90 \\
B & 0.61 \\
C & 0.44 \\
D & 0.38 \\
E & 0.31 \\
F & 0.27 \\
G & 0.18 \\
H & 0.13 \\
\hline olvent system: Ethyl acetate: Hexane $(2: 8, \mathrm{v} / \mathrm{v})$
\end{tabular}

Table 4 TLC purification of the CEE extract

\begin{tabular}{cl}
\hline Spot & Rf value \\
\hline A & 0.94 \\
B & 0.83 \\
C & 0.75 \\
D & 0.60 \\
E & 0.54 \\
F & 0.19 \\
\hline Solvent system: Ethyl acetate: Hexane $(8: 2, \mathrm{v} / \mathrm{v})$
\end{tabular}

Table 5 TLC purification of the CME extract

\begin{tabular}{ll}
\hline Spot & R $_{\mathbf{f}}$ alue \\
\hline A & 0.96 \\
B & 0.90 \\
C & 0.64 \\
D & 0.46 \\
E & 0.34 \\
\hline
\end{tabular}

Solvent system: Methanol: Chloroform (1:5 v/v)

The TLC chromatogram of the CNE, CEE and CME showed eight, five and five spots respectively when suitable solvent systems were employed. These results showed that the CNE, CEE and CME extracts mixtures has at least eight, five and five components respectively since some components may have such similar polarities that they appear under one spot after development.

\section{Conclusion}

The present study summarizes that $O$. basilicum is a good source of important secondary metabolites which are responsible for its diverse pharmacological application. The different solvent extracts showed promising broad spectrum antimicrobial activity and hence could be a potential source of natural antimicrobial agent. These results encourage researchers to do further in vitro and in vivo researches that will explore the role of bioactive constituents responsible for these activities as well as carry out studies at molecular level. 


\section{Compliance with ethical standards}

\section{Acknowledgments}

The authors will like to thank the staff of the Department of Pharmaceutical Microbiology, Usmanu Danfodiyo University Sokoto for their technical assistance in conducting this research.

\section{Disclosure of conflict of interest}

The authors declare that they have no conflict of interests and are solely responsible for all the contents and writings presented in this research work.

\section{References}

[1] Jain RA, Agarwal RC, Pandey A. and Jain R. (2011). Evaluation of Argemone mexicana fruits extract using micronucleus assay in mouse bone marrow cells. Bulletin of Pharmaceutical Research, 1(2), 22-24.

[2] Agarwal A, Bora D, Agarwal C, Kumar R and Choudhary V. (2015). CNS stimulant and antidepressant activity of seeds of Abelmoschus esculentus in rats. Bulletin of Pharmaceutical Research, 5(2), 47-50.

[3] Shrestha DK, Sapkota H, Baidya P and Basnet S. (2016). Antioxidant and antibacterial activities of Allium sativum and Allium cepa. Bulletin of Pharmaceutical Research, 6(2), 50-55.

[4] Fabricant DS and Farnsworth NR. (2001). The value of plants used in traditional medicine for drug discovery. Environmental Health Perspectives, 109(1), 69-76.

[5] Motaleb MA. (2011). Selected medicinal plants of Chittagong hill tracts. International union of conservation of nature and natural resources, $1-3$.

[6] Finch RG. (1998). Antibiotic resistance. Journal of Antimicrobial Chemotherapy, 42(2), 125-128.

[7] Iwu MW, Duncan AR and Okunji CO. (1999). New antimicrobials of plant origin. In: Janick J. (Ed) Perspectives on New Crops and New Uses. ASHS Press, Alexandria, 457-462.

[8] Kunin CM. (1993). Resistance to antimicrobial drugs a worldwide calamity. Annals of Internal Medicine, 12(1), 564-582.

[9] Mohammad A, Moghaddam D and Shayegh J. (2011). Antimicrobial activity of essential oil extract of Ocimum basilicum L. leaves on a variety of pathogenic bacteria. Journal of Medicinal Plants Research, 5(1), 3453-3456.

[10] Daneshian A, Gurbuz B, Cosge B and Ipek A. (2009). Chemical components of essential oils from basil (Ocimum basilicum L.) grown at different nitrogen levels. International Journal of Natural and Engineering Sciences, 3(3), 9-13.

[11] Naghibi F, Mosaddegh M, Mohammadi MM and Ghorbani A. (2005). Labiatae family in folk medicine in Iran: from ethnobotany to pharmacology. Iran Journal of Pharmaceutical Research, 4(2), 63-79.

[12] Paton A, Harley MR and Harley MM. (1999). Ocimum: an overview of classification and relationships. Basil: the genus Ocimum. CRC press, Amsterdam, The Netherlands, 1-38.

[13] Shafique M, Khan SJ and Khan NH. (2011). Study of antioxidant and antimicrobial activity of sweet basil (Ocimum basilicum) essential oil. Pharmacology online, 1(1), 105-111.

[14] Stalh E. (1973). Drug analysis by chromatography and microscopy. A Practical Supplement to Pharmacopoeias. (1st Ed.). Michigan, Ann Arbor, 219 - 224.

[15] Trease EA and Evans WC. (1978). Pharmacognosy. (11 th Ed.). London: Churchill Livingstone Harcourt Health Service, $60-75$.

[16] Sofowora A. (1982). Screening plants for bioactive agents. In medicinal plants and traditional medicine in Africa. Ibadan Spectrum Books Ltd, 289.

[17] MacFaddin JF. (2000). Biochemical Tests for Identification of Medical Bacteria. 3rd Edition, ASM Press, Washington DC.

[18] Fobres BD and Sham A. (2002). Weissfield. Diagnostic Microbiology. 11th Edition, Andrew Allen Press, Canada. 
[19] Leboffe MJ and Pierce BE. (2002). Microbiology Laboratory Theory and Application. 1 ${ }^{\text {st }}$ Edition, Morton Publishers, USA.

[20] Sneath PHA, Mair NS, Sharpe ME and Holt JG. (1986). Bergey's Manual of Systematic Bacteriology. Vol. 2, Williams and Wilkins, Philadephia.

[21] Miles AA and Misra SS. (1938). Estimation of bacterial power of blood. Journal of Hygiene, 38(1), $732-749$.

[22] Sajid N, Nizam B, Sajid B, Tamina N and Yasser MSSA. (2013). In vitro antimicrobial, antitumor, cytotoxic activities of the methanolic activities and its fractions of Acantolimon losgiscapum. International Journal of Phytopharmacology, 4(3), 179 - 183.

[23] Kavanagh F. (1972). Analytical Microbiology. F. Kavanagh (ED), VOLII, Academic press, New York, 11.

[24] Adham AN. (2015). Comparative extraction methods, phytochemical constituents, fluorescence analysis and HPLC validation of rosmarinic acid content in Mentha piperita, Mentha longifolia and Ocimum basilicum. Journal of Pharmacognosy and Phytochemistry, 6(1), 130-139.

[25] Anudurga G, Vidhya T, Suji T, Dhatchayani R and Jayanthi A. (2016). Antimicrobial, antioxidant and anticancer screening of Ocimum basilicum seeds. Bulletin of Pharmaceutical Research, 6(3), 114-119.

[26] Maryam A and Saba I. (2016). Phytochemical screening and antibacterial activities of essential oil, ethanolic and methanolic extracts of Ocimum basillicum L. Pakistan Journal of Biochemistry and Molecular Biology, 49(2), 3639.

[27] Adiguzel A, Gulluce M, Sengul M, Ogutcu SF and Ka-raman I. (2005). Antimicrobial activity of various extracts of Ocimum basilicum L. and observation of the inhibition effect on bacterial cells by use of scanning electron microscopy. Turkish Journal of Biology, 29(1), 155-156.

[28] Adamu HM, Abayeh OJ, Agho MO, Abdullahi AL, Uba A, Dukku HU and Wufem BM. (2005). An ethnobotanical survey of Bauchi State herbal plants and their antimicrobial activity. Journal of Ethnopharmacology, 99(1), 1-4.

[29] Adam AZ and Omer AF. (2015). Antibacterial activity of Ocimum basillicum (Rehan) leaf extract against bacterial pathogens in Sudan. Asian Journal of Research in Chemistry, 3, 94-99.

[30] Cooper J, Niggli U and Leifert C. (2006). Handbook of organic food safety and quality. Woodhead Publishing Limited, Abington Hall, Abington, Cambridge, CB1 6AH, England.

[31] Gatsing D, Nkeugoauapi CFN, Nkah, BFN, Kuiate JR and Tchouanguep FM. (2010). Chenopodium ambrosioides Linn. an indigenous medicinal plant. African Journal of Pharmacy and Pharmacology, 8(8), 231 - 234.

\section{How to cite this article}

Yelwa AS, Ogbiko C, Yakubu Y, Usman H and Lawal SI. (2018). Phytochemical screening, in vitro antibacterial and partial TLC purification of different solvents extracts of Ocimum basilicum L. GSC Biological and Pharmaceutical Sciences, 5(2), 132-138. 